\title{
Yeast-like fungi in Dominican amber
}

\author{
JOUKO RIKKINEN and GEORGE O. POINAR, JR.
}

RIKKINEN, J. \& POINAR, G. O. JR. 2002: Yeast-like fungal cells in Dominican amber. - Karstenia 42: 29-32. Helsinki. ISSN 0453-3402.

\begin{abstract}
Hundreds of yeast-like fungal cells were found in a fragment of Dominican amber dating back to 15-45 million years ago. While yeast-like fungi are common and important in many extant ecosystems, fossils of these morphs have not been reported previously. All evidence indicates that the fossilised fungi lived in a moist tropical forest and utilised a fluid substrate, possibly plant exudate.
\end{abstract}

Key words: Fossil fungi, Dominican amber, palaeoecology, yeasts

Jouko Rikkinen, Department of Applied Biology P. O. Box 27, FIN-00014 University of Helsinki, Finland

George Poinar, Department of Entomology, Oregon State University, 2046 Cordley Hall, Corvallis, Oregon 97331-2907, USA

\section{Introduction}

Because of their microscopic size, soft cells, and ephemeral nature, yeast-like fungi are not likely candidates for preservation as fossils. However, the occurrence of many taxonomically distant yeasts in modern ecosystems is one rationale suggesting the antiquity of an yeast-like morphology. Also many aspects in the ecology of extant yeasts, i.e., their common occurrence in the slime fluxes of trees and in close association with wood-boring insects, would indicate that amber has a high potential for extending their fossil record. Here we describe and illustrate some yeast-like cells that were found among other biological inclusions in a fragment of Dominican amber. While fungi are known in the fossil record from a number of geologic time periods, the only previous reports of yeast-like fungi in amber are those of two filamentous taxa, possibly related to extant Geotrichum (Taylor 1994; Taylor \& Taylor 1993; Stubblefield et al. 1985; Rikkinen $\&$ Poinar 2001). As to other fungal organisms in Dominican amber, several species of ascomycetes and basidiomycetes, one zygomycete, and one plasmodial slime mould have been reported
(Poinar \& Singer 1990; Waggoner \& Poinar 1992; Hibbett et al. 1997; Poinar \& Poinar 1999; Poinar et al. 2000).

\section{Material and methods}

The fossilised fungal cells are contained in large fragment $(40 \times 36 \times 3 \mathrm{~mm})$ of clear light yellow amber (Poinar B 1-23, in Poinar amber collection maintained at Oregon State University, USA). The specimen originated from the amber mines in the Cordillera Septentrional of the Dominican Republic. These mines are in the El Mamey Formation (Upper Eocene), which is a shalesandstone interspersed with a conglomerate of wellrounded pebbles (Poinar 1992). Dominican amber is fossilised exudate of the now-extinct leguminous trees $\mathrm{Hy}$ menaea protera (Poinar 1991). During fossilisation terpenoid materials of the exudate were progressively oxidised and polymerised to a point where they became resistant against chemical and biological degradation. The exact age of Dominican amber is unknown, with estimates ranging from 15-20 million years on the basis of foraminifera counts to $30-45$ million years from studies with coccolith fossils (Poinar \& Poinar 1999).

The amber specimen has been cut and polished to facilitate screening for inclusions. In this study no further destructive sampling was performed. All measurements and photographs were taken from the intact specimen under transmitted and/or incident light. Opti- 
cal distortions were neutralised by coating the specimen in vegetable oil. The deep field of focus in Figure 2 was achieved by combining several optical sections into one composite picture.

\section{Results and discussion}

The amber specimen contains a multitude of biological inclusions, including several species of bryophytes, a small foliose lichen, and a well preserved fungal mycelium, approx. $2.0 \times 1.75 \mathrm{~mm}$ in diam. (Rikkinen \& Poinar 2001). The peripheral, expanding regions of the coenocytic mycelium are composed of hyaline, moderately branched hyphae. Some hyphae had produced cylindrical arthroconidia similar to those of Geotrichum and related yeasts. Other hyphae had produced terminal and intercalary protuberances similar to the sporangia of some extant zygomycetes and oomycetes. Many fossilised conidia and spores had germinated prior to preservation (Rikkinen \& Poinar 2001).

In the central parts of the fossilised mycelium the hyphae are largely replaced by unicellular, yeast-like morphs (Figs 1-2). The yeast-like cells occur singly, in pairs, or in small groups embedded in an amorphous, cloudy matrix. Although in close proximity of hyphae, the cells are not attached to the mycelium. The hyphae themselves

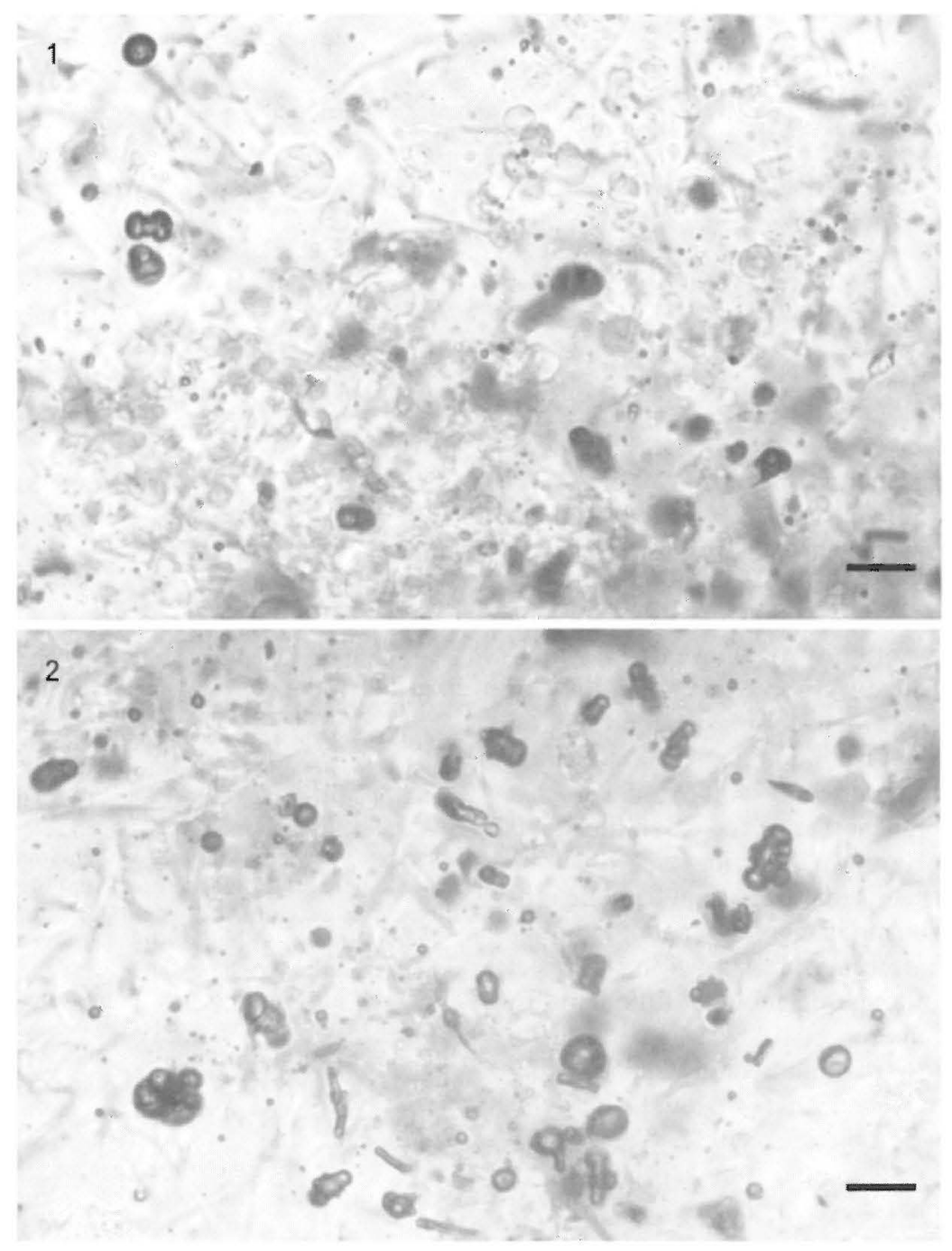

Figs 1-2. Yeast-like cells and other fungal microfossils in Dominican amber (Poinar B 1-23). Scale bars $10 \mu \mathrm{m}$. 
do not show clear evidence of budding, but some of them have produced arthroconidia by fragmentation. Neither does the size and shape of the cells correspond with the globular spore-like objects inside some hyphal protuberances, tentatively identified as sporangia (Rikkinen \& Poinar 2001). Thus, the mycelial hyphae and the yeast-like cells seem to represent at least two different organisms that lived and were preserved together.

The yeast-like cells are variable in shape, mostly globose or subglobose, $2-5$ (7) $\mu \mathrm{m}$ in diam. While the cellular contents of some cells may have been preserved, many of the fossils represent highly refractive casts of cells at different stages of development (Figs 1-4). Some cells show evidence of budding, which sometimes has resulted in compact clusters of cells (Figs 2-3). Others had produced broad hyphal protuberances and there are also many dumbbell shaped pairs of cells, raising the possibility of conjugation (Figs 1-4).

The terms "yeast" and "yeast state" have been applied to the budding unicellular phase or phases in fungal life histories. Also fungi which form short hyphal fragments or cellular aggregates are often referred to as yeast-like. However, differences between the various morphs (unicel-

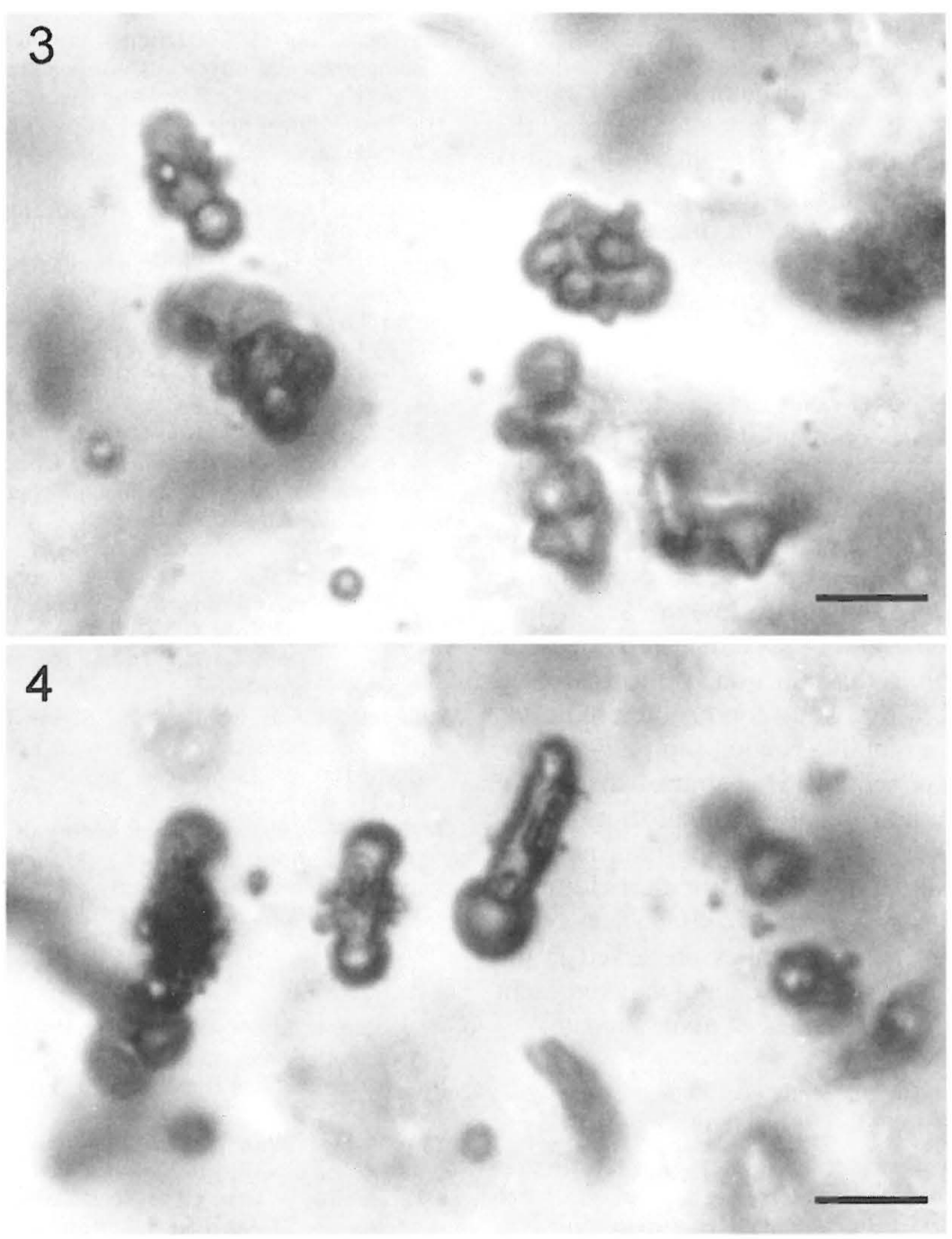

Figs 3-4. Yeast-like cells in Dominican amber (Poinar B 1-23). Scale bars $5 \mu \mathrm{m}$. 
lular, yeast-like and pseudohyphal) are not always clear. The fossilised cells resemble yeastlike morphs produced from germinating spores of some filamentous Euascomycetes. Many Archiand Euascomycetes have yeast-like phases in their life cycles and these are easily confused with true yeasts, i.e. those with saccharomycetous or basidiomycetous affinities (de Hoog 1998). Few yeast-like fungi can be confidently identified by morphology alone. Furthermore, also some non-fungal organisms, like heterotrophic algae of the genus Prototheca, are yeastlike in appearance (Pore 1998). Many yeasts are readily distinguished by a combination of morphological, ultrastructural and cultural characteristics, but sometimes mating tests and/or molecular analyses are required (Kurtzman 1998; Yarrow 1998). As ultrastructural details cannot be examined without the risk of damaging the fossil, and since the fossilised cells are quite likely to represent several taxa, no attempt is made to assign the fossils to an extant fungal group.

Biological inclusions in the amber specimen indicate an epiphytic or epixylic microhabitat in a moist tropical forest. The bryophytes belong to extant genera, which are widely distributed in tropical rainforests (Frahm 1993; Gradstein 1993). The cryptogamic community seems to have been entrapped in place by viscous exudate running down a tree trunk or dripping from the forest canopy. The occurrence of actively reproducing yeast-like cells indicates a sudden event during moist conditions, otherwise favourable for fungal growth. The amber specimen provides few details regarding the nutrition of the fossilised fungi. The lack of a solid food source indicates that they were rapidly growing saprophytes, utilising a fluid or semisolid substrate. Most extant yeasts live in nutritionally rich substrates, such as rotting plant material, food-stuffs or polluted water, and many species are particularly found in slime fluxes of trees (Batra 1987; Berryman 1989). Indeed, some opaque globules preserved in the vicinity of the fossilised mycelium may represent inertly dehydrated droplets of plant exudate.

Acknowledgments: This study was made possible by financial support from the Academy of Finland.

\section{References}

Batra L. R. 1987: Insect-associated, filamentous endomycetes - their growth and strategies for survival. - Stud. Mycol. 30: 415-428.
Berryman, A. A. 1989: Adaptive pathways in scolytidfungus associations. - In: Wilding, N., Collins, N. M., Hammond, P. M. \& Webber, J. F. (eds.): Insect-Fungus Interactions: pp. 145-159. Academic Press. Cambridge.

Frahm, J. P. 1993: Mosses in Dominican amber. - J. Hattori Bot. Lab. 74: 249-259.

Gradstein, S. R. 1993: New fossil Hepaticae preserved in amber of the Dominican Republic. - Nova Hedwigia 57: $353-374$.

Hibbett, D. S., Grimaldi, D. \& Donoghue, M. J. 1997: Fossil mushrooms from Miocene and Cretaceous ambers and the evolution of homobasidiomycetes. - Am. J. Bot. 84: 981-991.

de Hoog, G. S. 1998: A key to the anamorph genera of yeastlike Archi- and Euascomycetes. - In: Kurtzman, C. P. \& Fell J. W. (eds.), The Yeasts: a Taxonomic Study, $4^{\text {th }}$ ed., pp. 123-125. Elsevier. Amsterdam.

Kurtzman, C. P. (1998). Discussion of teleomorphic and anamorphic ascomycetous yeasts and a key to genera. - In: Kurtzman, C. P. \& Fell J. W. (eds.), The Yeasts: a Taxonomic Study, $4^{\text {th }}$ ed., pp. 111-121. Elsevier. Amsterdam.

Poinar, G. O., Jr. 1991: Hymenaea protera sp. n. (Leguminosae, Caesalpinioideae) from Dominican amber has African affinities. - Experientia 47: 1075-1082.

Poinar, G. O., Jr. 1992: Life in Amber. - 360 pp. Standford University Press. Standford.

Poinar, G. O., Jr. \& Poinar, R. 1999: The Amber Forest. - 239 pp. Princeton University Press. Princeton.

Poinar, G. O., Jr., Peterson, E. B. \& Platt, J. L. 2000: Fossil Parmelia in New World amber. - Lichenologist 32: 263-269.

Poinar, G. O., Jr. \& Singer, R. 1990: Upper Eocene gilled mushroom from the Dominican Republic. - Science 248: 1099-1101.

Pore, R. S. (1998): Prototheca Krüger. - In: Kurtzman, C. P. \& Fell J. W. (eds.), The Yeasts: a Taxonomic Study, $4^{\text {th }}$ ed., pp. 883-887. Elsevier. Amsterdam.

Rikkinen, J. \& Poinar, G. O., Jr. 2001: Fossilised fungal mycelium from Tertiary Dominican amber. - Mycol. Res. 105: 890-896.

Stubblefield, S. P., Miller, C. E., Taylor, T. N. \& Cole, G. T. 1985: Geotrichites glaesarius, a conidial fungus from Tertiary Dominican amber. - Mycologia 77: 11-16.

Taylor, T. N. 1994: The fossil history of ascomycetes. In: Hawksworth, D. L. (ed.), Ascomycete Systematics: problems and perspectives in the nineties: pp. 167-174. Plenum Press. New York.

Taylor, T. N. \& Taylor, E. L. 1993: The biology and evolution of fossil plants. - Prentice Hall. Englewood Cliffs.

Waggoner, B. \& Poinar, G. O., Jr. 1992: A fossil myxomycete plasmodium from Eocene-Oligocene amber of the Dominican Republic. - J. Protozool. 39: 639642.

Yarrow, D. (1998). Methods for the isolation, maintenance and identification of yeasts. - In: Kurtzman, C. P. \& Fell J. W. (eds.), The Yeasts: a Taxonomic Study, $4^{\text {th }}$ ed., pp. 77-99. Elsevier. Amsterdam. 